\title{
Some physicochemical, rheological and sensory properties of flavored ice cream
}

\section{Aromalı dondurmaların bazı fizikokimyasal, reolojik ve duyusal özellikleri}

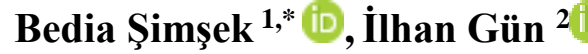 \\ ${ }^{1}$ Süleyman Demirel University, Faculty of Engineering, Department of Food Engineering, Isparta Turkey) \\ ${ }^{2}$ Burdur Mehmet Akif Ersoy University, Burdur Food, Agriculture and Livestock Vocational High School, Burdur, Turkey
}

\begin{abstract}
In this study, a total of 36 samples of each type of ice cream were collected from four different ice cream producers and determined some of the rheological and chemical properties at three different times. In regard the different flavors of ice cream, the differences between the $\mathrm{pH}$, dry matter, fat, protein, overrun, first trickle of melting time, $\mathrm{L} *$, a * and $\mathrm{b}^{*}$ values were found to be statistically significant. All the samples displayed non-Newtonian behavior and pseudoplastic flow behavior. The apparent viscosity at $20{ }^{\circ} \mathrm{C}$ under a shear rate of $50 \mathrm{~s}^{-1}$ was determined to be 7.722.17 Pa•s, 0.14-0.85 Pa・s and 0.59-1.28 Pa•s for the chocolate, strawberry, and vanilla ice cream samples, respectively. According to the principal component analysis (PCA) and hierarchical cluster analysis (HCA), it was determined that the ice creams were produced with different properties although the typical characteristics of the ice creams were the same
\end{abstract}

Keywords: Flavored ice cream, Rheological properties, Sensory evaluation

\section{Introduction}

Ice cream is a dairy product with refreshing features, pleasing aroma and appearance as a result of the addition of different fruit, which can be consumed in every season. In addition, ice cream can be produced as a plain product and its nutritional value and functional properties improved upon the addition of any flavor. A flavored ice cream has one or several flavored ingredients. Its flavor comes from a mixture of one or more products, such as cream, fruit, fruit juice, fruit pulp or paste, fruit juice concentrate, soluble coffee, ground cocoa, vanilla, vanillin, and processed hazelnut, which are commonly used in milk-based ice cream [1]. In addition, the increased consumption of ice cream in the summer months, especially for individuals who do not have milk drinking habits, is beneficial in terms of both nutrition and the dairy sector.

The direction of the recently reported studies has focused on the development of ice cream formulations for the market. Therefore, researchers have begun to study the detection of the sensory and rheological properties of ice creams produced using these new formulations. The investigation of the rheological properties of foods is of the utmost importance for process regulation, evaluation, structural organization of foods and consumer pleasure $[2,3]$.
Özet

Bu çalışmada, dört farklı dondurma üreticisinden her bir dondurma çeşidinden toplam 36 numune toplanmış ve üç farklı zamanda bazı reolojik ve kimyasal özellikler belirlenmiştir. Dondurmanın farklı aromaları açısından $\mathrm{pH}$, kuru madde, yağ, protein, hacim artışı, ilk damlama zamanı, $\mathrm{L} *$, a * ve $\mathrm{b} *$ değerleri arasındaki farklar istatistiksel olarak anlamlı bulunmuştur. Tüm örnekler, Newton yasalarına uygun olmayan davranış ve psödoplastik akış davranışı göstermektedir. $20{ }^{\circ} \mathrm{C}^{\prime} \mathrm{de} 50 \mathrm{~s}^{-1}$ kesme hızı altında görünen viskozite, çikolata, çilekli ve vanilyalı dondurma örnekleri için sırasıyla 7.72-2.17 Pa•s, 0.14-0.85 $\mathrm{Pa} \bullet \mathrm{s}$ ve $0.59-1.28 \mathrm{~Pa} \bullet \mathrm{s}$ olarak belirlenmiştir. Temel bileşen analizi (PCA) ve hiyerarşik küme analizine (HCA) göre, dondurmaların çeşit özellikleri aynı olsa da dondurmaların farklı özelliklerde üretildiği belirlenmiştir.

Anahtar kelimeler: Aromalı dondurma, Reolojik özellikler, Duyusal değerlendirme

Tekinsen [4] states that 240 kinds of ice cream can be found in the ice cream sector. The most consumed types of ice cream contain vanilla (or vanillin), chocolate (or cocoa) and fruit (strawberry, lemon, etc.). There are many studies on the development of new ice cream formulations with different ingredients, such as cola extract [5], black tea and herbal tea [6], being used. There are also studies on how different substances affect the consistency of ice cream [3, 7] and how fat substitutes affect the freezing properties of ice cream [8].

Although the chemical, structural and microbiological properties of ice creams vary according to the parameters used in their production, the structural and chemical properties of the flavorings used in the production of ice cream and their effect of the usage rates are very important. The aim of this study is to identify and compare some of the chemical, sensory, textural, and rheological properties of ice creams containing different flavors that are presently consumed in the current market.

\section{Material and methods}

\subsection{Materials}

All research materials were obtained from four small and medium-sized ice cream producers located in Isparta

\footnotetext{
* Sorumlu yazar / Corresponding author, e-posta / e-mail: bediasimsek@sdu.edu.tr (B. Şimşek)

Geliş / Recieved: 07.04.2021/ Kabul / Accepted: 20.04.2021 Yayımlanma / Published: 27.07.2021

doi: $10.28948 /$ ngmuh. 911167
} 
Province-Turkey. Three samples of flavored ice cream were collected from each producer on three different occasions: Vanilla (or vanillin), chocolate and strawberry. With this arrangement, a total of 36 samples were analyzed.

The samples were placed in sterile glass jars and the rheological, physical, and chemical analyses were carried out immediately after they were brought to the laboratory in accordance with Turkish Standard [9].

\subsection{Methods}

\subsubsection{Physicochemical analysis}

The total solids, fat, and protein content in the ice cream samples were analyzed according to Official Methods of Analysis [10]. The $\mathrm{pH}$ values of the ice cream samples were measured using a $\mathrm{pH}$-meter combined with a glass electrode (WTW pH 315 (Weilheim, Germany).

\subsubsection{Melting characteristics}

Melting behaviour which indicative of the melting properties and first dropping time, were detected using samples stored at $-20{ }^{\circ} \mathrm{C}$. The melting properties were carefully analysed in the ice cream samples weighing about $60 \mathrm{~g}$ which placed onto a $1 \mathrm{~mm}$ stainless steel screen placed over a cup. The amount of ice cream drained into the cup was measured at $26 \pm 0.5^{\circ} \mathrm{C}$. The first dropping time of samples was also determined [11]. The melting time was calculated according to the amount of melted ice cream collected after the first drop over $4 \mathrm{~h} \mathrm{[12].}$

The overrun was calculated as the ratio of the weight of the ice cream mix to its weight after freezing. The formula given as follows was used in the calculate of overrun;

Overrun $(\%)=($ weight of ice cream mixture $)-($ weight of ice cream $) \times 100 \times(\text { weight of ice cream })^{-1}$ [13]

\subsubsection{Color measurements}

The color of the ice cream samples was measured using a colorimeter (Minolta (CR-400), Japan) as the $\mathrm{L}^{*}$ (the lightness from black to white on a $0-100$ scale), a* (red (+) or green (-) ) and $b^{*}$ (yellow (+) or blue (-)) values.

\subsubsection{Textural analysis}

Samples were stored at $-15{ }^{\circ} \mathrm{C}$ for 24 hours before determining the hardness in ice creams. A texture analyser (Stable Microsystems Ltd, TA-XT2i, Surrey, UK) was used to determine the textural properties of the samples. Measurements were determined in five measurements with a $36 \mathrm{~mm}$ stainless steel cylindrical probe (P / 36R) attached to a $2 \mathrm{~kg}$ load cell. The penetration depth was set to $10 \mathrm{~mm}$ and the penetration speed to $2.0 \mathrm{~mm} / \mathrm{s}$ in the analyses.

\subsubsection{Rheological measurements}

A rotational viscometer (Model DV-II-pro; Brookfield Engineering Inc., MA, USA) equipped with a UL small sample adapter was used to measure the viscosity of samples. The viscosity measurements were carried out in all ice cream samples at $10^{\circ} \mathrm{C}$.

The shear rate, shear stress and apparent viscosity value of samples were determined. Consequently, the consistency index and power law model (Eq (2)) were recorded [14]:

$$
\eta=K \gamma^{\mathrm{n}-1}
$$

where $\eta$ is the apparent viscosity (Pas), $K$ is the consistency coefficient $(\mathrm{Pa} \mathrm{sn}), \gamma$ is the shear rate $\left(\mathrm{s}^{-1}\right)$ and $n$ (dimensionless) is the flow behaviour index.

The apparent viscosity of the ice cream samples was calculated at a shear rate of $50 \mathrm{~s}^{-1}\left(10^{\circ} \mathrm{C}\right)$, which represents the sensing shear rate in the mouth of low viscosity foods [15].

\subsubsection{Sensory assessment}

Eleven experienced panelists were selected and trained to evaluate their sensory characteristics (two sessions) [16-18].

While the texture, appearance, and flavor of the samples were evaluated together, their melting properties were determined separately. Ice cream samples, coded using random numbers, were evaluated by panellists in special cabinets.

The ice cream was preserved at -15 for 24 hours before being the sensory evaluation. The samples were given to the panellists in plastic plates in the form of two balls in approximately $20 \mathrm{~g}$ portions. The intensity of the flavor was evaluated by its sweet, acidic, insipid, milk and cream characteristics. The texture was evaluated using five descriptors including gummy, stickiness, fragile, frosted and orodispersible structure. The appearance was evaluated using the terms glossy, moire and granular.

To determine the melting quality, $10 \mathrm{~g}$ of each ice cream sample was left at room temperature for 15 minutes to thaw. In addition, the appearance, texture, odor, flavour, and general acceptability of ice cream samples were evaluated using a 5 -point scale ( $1=$ unpleasant, non -acceptable, $5=$ pleasant, no criticism).

\subsubsection{Statistical analyses}

All analyzes applied to ice cream were repeated three times. SPSS 17.0 was used for the statistical evaluation of the analyzes. Variance analysis was applied to the results, and Tukey test was used to determine the differences within the groups. In addition, the statistical evaluation of the data was made with one-way ANOVA.

Principal component analysis and cluster analysis were implemented to investigate the correlation between the instrumental and sensory properties and used to find the similarities between the flavored ice cream samples.

\section{Results and discussion}

\subsection{Chemical and physical properties}

While ice cream is a dairy product with high nutritional value, its chemical properties may vary depending on the ingredients used in its production. In particular, the quality of the flavorings as well as the composition and freshness of the milk used in the production of ice cream directly affect the product's properties. The materials used in the production of ice cream can affect the acidity of the ice cream mixture. In this study, it was observed that the $\mathrm{pH}$ values of the ice creams obtained from the different manufacturers varied between $\mathrm{pH} 3.49$ and 7.37 (Table 1). The $\mathrm{pH}$ value of the strawberry ice cream samples was significantly different from those of the vanilla and chocolate 
ice cream samples $(p<0.05)$. The main reasons for this difference can be ascribed to the use of fruit, the acidity and the amount of the fruit used in production and the use of cocoa or chocolates from different sources [19]. It is also thought that the use of cocoa in the production of ice cream obtained from different sources creates this difference. The acidity of the ice cream mixture is affected because alkaline cocoa powder adjusted to $\mathrm{pH} 8.0$ is commonly used instead of natural cocoa powder, which has a $\mathrm{pH}$ value of 5.0-5.8.

The composition and processing of the mixture used in ice cream production is extremely important in terms of the ice cream's quality. It would be good to comment the results of overrun, fat and dry matter according to the Turkish Food Codex. The dry matter values of the ice cream samples used in the study were determined to be between 32.13 and $44.09 \%$ (Table 1). In a study on fruit ice cream, it was determined that the dry matter contents changed between 29.64 and $34.36 \%$ in strawberry ice [20]. In the same study it was also found that the dry matter values varied between 27.72 and $37.79 \%$ in lemon ice cream, $29.38-40.33 \%$ in sour cherry ice cream. The dry matter values of the samples vary depending on the composition of the milk and the materials used during the production process, depending on whether the flavoring is fibrous or juicy, the use ratio or the powder form, which can increase the dryness as well as the pasteurization temperature and duration.

Milk fat is an important component in the structure and flavor of ice cream. The lowest fat level in the ice cream samples studied was $0.10 \%$ (C3). The fat content in the strawberry ice cream samples was significantly different to those of the other samples ( $\mathrm{p}<0.05)$. In a study on fruit ice cream, it was determined that the fat content of the samples varied between $0.5-2.6 \%$ in lemon ice cream, $0.6-3.8 \%$ in sour cherry ice cream and $0.2-2.4 \%$ in strawberry ice cream [20].

Another important component in addition to the fat content in regard the structural properties of ice cream is the protein content. In our study it was determined that the protein content of chocolate ice cream was higher than those of the other ice cream samples. The highest protein content was found in the K1 sample $(5.503 \%)$ and the lowest protein content was found in strawberry ice cream $(0.631 \%)$ (Table $1)$. The use of milk and/or dairy products in the ice cream mixture also affects the protein content. In a study on Kahramanmaras type ice cream, it was reported that the protein content changed between 3.49 and $3.60 \%$ [21]. In a study on fruit ice cream, it was determined that the protein content in the samples studied varied between 0.62 and $2.6 \%$ in lemon ice cream, $0.71-3.8 \%$ in sour cherry ice cream and $0.21-2.4 \%$ in strawberry ice cream [20].

During the production of ice cream, the overrun refers to the increase in volume when the liquid is mixed with air during the churning process. In the ice cream samples studied, the overrun varied between 28.42 and $46.97 \%$ in vanilla ice cream, $24.02-33.73 \%$ in chocolate ice cream and $30.86-32.67 \%$ in strawberry ice cream (Table 1). In our study, there was no statistically significant difference between the overrun values obtained for the other ice creams samples except for vanilla ice cream $(\mathrm{p}<0.05)$. Celik et al.
(2010) determined the overrun was 35.93-48.94\%, while Tekinsen \& Karacabey [4] determined the overrun value in ice cream was between $27 \%$ and $38 \%$. In Kahramanmaras type ice cream, Guven et al. [22] determined the overrun to be $21.74 \%$.

When the first dripping property was examined, and its durability during consumption, it was determined that the samples showed a value between 8.24-17.92 min (Table 2). In general, it was observed that the vanilla and chocolate ice creams tend to melt faster than strawberry ice cream. Atsan and Caglar [23] found that the first dripping time in the control sample was $58.97 \mathrm{~min}$ in their study on the effects of different emulsifiers during ice cream production.

Similarly, it was also stated that the different fat substitutes added to the ice cream mixture have a significant effect on the penetrometer values of Maras ice cream, including the first dripping times and complete melting times, and the melting rates [24].

The full melting values of the ice creams obtained from the different places of production are given in Table 2. The complete melting values of samples varied between 45.39 and $61.13 \mathrm{~min}$ and the statistical difference between the samples was significant ( $\mathrm{p}<0.05)$. Antepuzumu (2005) determined the full melting value as $2.72-41.24 \mathrm{~min}$ in ice creams prepared with the addition of different honey components, while the stabilizers used in different types of ice cream is especially important, it is stated that the fat content in the ice cream composition is also an important factor for its melting time [25].

The color obtained from ice cream technology should also reflect the product's characteristics. Nowadays, as color analysis, most $\mathrm{CIE} \mathrm{L} * \mathrm{a} *$ and $\mathrm{b} *$ color values are examined. As shown in Table 2, the $\mathrm{L}^{*}$ value ranged from 71.26 to 86.39 in vanilla ice cream, $34.62-44.38$ in chocolate ice cream and 46.67-82.16 in strawberry ice cream. Our statistical evaluation showed that the $\mathrm{L}^{*}$ values varied between the varieties $(p<0.05)$, whereas the $L^{*}$ values obtained for the ice cream samples from the different manufacturers were not statistically significant $(p>0.05)$.

In some previous studies, the $\mathrm{L}^{*}$ values of lemon fiber ice creams were measured to be 78.21-85.57 (Dervisoglu \& Yazici, 2006) and strawberry flavored ice creams containing soy concentrate were measured to be between 72.34 and 77.7 ice cream are especially important, it is stated that the fat content in the ice cream composition is also an important factor for its melting time [26].

The a*values obtained from the measurements made from the outer section of the flavored ice creams produced by the different manufacturers are given in Table 2 . The $a^{*}$ values of the samples were found to change between 1.99 5.94 in vanilla ice-cream, 11.61-13.13 in chocolate icecream and 20.68-35.14 in strawberry ice-cream. This value was determined by Dervisoglu and Yazici [5] to be between 3.55-4.43 in fruit-fiber ice cream

The $\mathrm{b} *$ values were determined to be between 9.53 and 23.47 for vanilla ice cream, 6.80-9.82 for chocolate ice cream and 4.28-23.47 for strawberry ice cream (Table 1). The $\mathrm{b} *$ value in kefir ice cream was measured to be between 1.41 and 6.58 [27]. In a study on fruit-flavored yogurt, the b 
* values were found to be in a narrower range (0.74 and 3.46) than those observed in our study [28]. The formulation of the ice cream mixture, the coloring ability of the fruit used in the product, the manner in which the flavors are obtained and their coloring properties, the maturity ratings of the fruits, the heat treatment grades and times applied during processing, the product preservation conditions, and the chemical degradation of the fruits affect the color quality of the final product.

It has been reported that there is an inverse relationship between the overrun and hardness, and ice cream samples with low overrun values show harder structures [29]. The hardness measurement results obtained using the texture analyzer are given in Table 2. According to the hardness measurements, the chocolate sample K2 $(144.18 \mathrm{~N})$ and the vanilla sample V2 $(144.19 \mathrm{~N})$ have the highest values. The lowest hardness value was detected in strawberry ice cream sample C2 (38.47 N).

The hardness values of the ice cream types differed according to the statistical evaluation ( $\mathrm{p}<0.05)$, but it was determined that there was no significant difference between the hardness values observed for the different manufacturers.

Table 1. Physicochemical properties of flavored ice cream samples

\begin{tabular}{|c|c|c|c|c|c|}
\hline Sample & pH & Total Solid \% & Fat $\%$ & Protein \% & Overrun \% \\
\hline V1 & $6.31 \pm 0.38^{b}$ & $37.38 \pm 0.77^{\mathrm{bc}}$ & $3.65 \pm 0.70^{\mathrm{a}}$ & $4.84 \pm 1.17^{\mathrm{a}}$ & $28.42 \pm 1.74^{b}$ \\
\hline V2 & $6.56 \pm 0.08^{\mathrm{ab}}$ & $33.94 \pm 0.35^{\mathrm{c}}$ & $3.21 \pm 0.25^{\mathrm{a}}$ & $4.16 \pm 1.13^{\mathrm{a}}$ & $46.97 \pm 3.50^{\mathrm{a}}$ \\
\hline V3 & $6.48 \pm 0.38^{\mathrm{ab}}$ & $34.84 \pm 0.49^{\mathrm{c}}$ & $3.78 \pm 0.51^{\mathrm{a}}$ & $4.38 \pm 0.66^{\mathrm{a}}$ & $30.97 \pm 2.30^{\mathrm{b}}$ \\
\hline V4 & $6.66 \pm 0.06^{\mathrm{ab}}$ & $35.21 \pm 0.93^{\mathrm{c}}$ & $3.60 \pm 0.52^{\mathrm{a}}$ & $4.29 \pm 0.22^{\mathrm{a}}$ & $31.74 \pm 5.19^{b}$ \\
\hline K1 & $6.68 \pm 0.43^{\mathrm{ab}}$ & $44.09 \pm 1.44^{\mathrm{bc}}$ & $4.10 \pm 0.65^{\mathrm{a}}$ & $5.50 \pm 0.93^{\mathrm{a}}$ & $28.02 \pm 2.20^{\mathrm{b}}$ \\
\hline K2 & $7.32 \pm 0.08^{\mathrm{a}}$ & $35.37 \pm 0.29^{c}$ & $3.08 \pm 0.42^{\mathrm{a}}$ & $3.92 \pm 0.52^{\mathrm{ab}}$ & $33.73 \pm 6.61^{b}$ \\
\hline K3 & $6.47 \pm 0.40^{\mathrm{ab}}$ & $36.65 \pm 0.66^{\mathrm{c}}$ & $3.51 \pm 0.52^{\mathrm{a}}$ & $4.33 \pm 0.19^{\mathrm{a}}$ & $28.65 \pm 4.83^{b}$ \\
\hline K4 & $7.37 \pm 0.10^{\mathrm{a}}$ & $37.52 \pm 0.19^{c}$ & $3.11 \pm 1.05^{\mathrm{a}}$ & $4.29 \pm 0.22^{\mathrm{a}}$ & $24.67 \pm 2.72^{b}$ \\
\hline $\mathrm{C} 1$ & $4.22 \pm 0.31^{\mathrm{d}}$ & $34.21 \pm 3.81^{\mathrm{a}}$ & $0.73 \pm 0.45^{b}$ & $1.16 \pm 0.67^{\mathrm{bc}}$ & $32.25 \pm 5.81^{b}$ \\
\hline $\mathrm{C} 2$ & $5.26 \pm 0.70^{\mathrm{c}}$ & $34.63 \pm 3.58^{\mathrm{ab}}$ & $4.36 \pm 1.27^{\mathrm{a}}$ & $2.81 \pm 1.00^{\mathrm{abc}}$ & $31.83 \pm 1.18^{\mathrm{b}}$ \\
\hline $\mathrm{C3}$ & $3.49 \pm 0.05^{\mathrm{d}}$ & $32.13 \pm 0.93^{\mathrm{a}}$ & $0.10 \pm 0.0^{\mathrm{b}}$ & $0.63 \pm 0.35^{\mathrm{c}}$ & $30.86 \pm 4.52^{\mathrm{b}}$ \\
\hline $\mathrm{C4}$ & $5.27 \pm 0.10^{\mathrm{c}}$ & $34.51 \pm 0.35^{\mathrm{bc}}$ & $2.93 \pm 0.50^{\mathrm{a}}$ & $4.63 \pm 2.11^{\mathrm{a}}$ & $32.67 \pm 1.87^{b}$ \\
\hline
\end{tabular}

V: vanilla ice cream, K: chocolate ice cream, C: strawberry ice cream

* a, b, c Means within a row with different lowercase letters show significant differences between ripening materials, $\mathrm{P}<0.05$

Table 2. Melting, color and hardness properties of ice cream samples

\begin{tabular}{|c|c|c|c|c|c|c|}
\hline Sample & $\begin{array}{c}\text { First } \\
\text { Dripping } \\
\text { time (min) }\end{array}$ & $\begin{array}{l}\text { Melting time } \\
\quad(\text { min) }\end{array}$ & $\mathbf{L}^{*}$ & $\mathbf{a}^{*}$ & $\mathbf{b}^{*}$ & Hardness (N) \\
\hline V1 & $8.24 \pm 3.45$ & $48.15 \pm 4.82^{\mathrm{bc}}$ & $84.75 \pm 0.45^{\mathrm{a}}$ & $2.73 \pm 0.09^{\mathrm{d}}$ & $9.53 \pm 0.64^{\mathrm{ab}}$ & $90.75 \pm 93.38^{\mathrm{ab}}$ \\
\hline V2 & $9.20 \pm 6.89$ & $53.75 \pm 2.56^{\mathrm{abc}}$ & $83.19 \pm 0.53^{\mathrm{a}}$ & $2.17 \pm 0.11^{\mathrm{d}}$ & $9.93 \pm 1.15^{\mathrm{ab}}$ & $144.19 \pm 82.44^{\mathrm{ab}}$ \\
\hline V3 & $8.71 \pm 3.63$ & $58.50 \pm 3.47^{\mathrm{ab}}$ & $71.26 \pm 20.08^{\mathrm{ab}}$ & $1.99 \pm 0.94^{\mathrm{d}}$ & $9.48 \pm 5.17^{\mathrm{ab}}$ & $77.49 \pm 25.46^{\mathrm{ab}}$ \\
\hline V4 & $12.24 \pm 2.19$ & $57.82 \pm 5.91^{\mathrm{ab}}$ & $86.39 \pm 1.14^{\mathrm{a}}$ & $5.94 \pm 0.40^{\mathrm{d}}$ & $13.47 \pm 2.04^{\mathrm{ca}}$ & $74.85 \pm 68.25^{\mathrm{ab}}$ \\
\hline K1 & $13.00 \pm 6.67$ & $45.39 \pm 1.20^{c}$ & $34.62 \pm 2.51^{\mathrm{c}}$ & $11.92 \pm 0.14^{\mathrm{cd}}$ & $6.80 \pm 2.25^{\mathrm{cd}}$ & $85.93 \pm 68.25^{\mathrm{a}}$ \\
\hline K2 & $14.07 \pm 3.71$ & $56.54 \pm 2.86^{\mathrm{abc}}$ & $39.80 \pm 3.63^{c}$ & $13.13 \pm 1.63^{\mathrm{bcd}}$ & $8.18 \pm 1.67^{\mathrm{c}}$ & $144.18 \pm 75.87^{\mathrm{a}}$ \\
\hline K3 & $19.68 \pm 5.07$ & $50.05 \pm 2.69^{\mathrm{abc}}$ & $44.38 \pm 1.82^{\mathrm{c}}$ & $12.94 \pm 0.74^{\mathrm{bcd}}$ & $9.82 \pm 1.78^{\mathrm{ab}}$ & $113.37 \pm 13.41^{\mathrm{a}}$ \\
\hline K4 & $15.37 \pm 2.16$ & $50.62 \pm 0.74^{\mathrm{abc}}$ & $37.34 \pm 3.64^{\mathrm{c}}$ & $11.61 \pm 1.69^{\mathrm{cd}}$ & $7.58 \pm 0.97^{\mathrm{cd}}$ & $115.53 \pm 27.44^{\mathrm{a}}$ \\
\hline C1 & $13.88 \pm 2.77$ & $52.37 \pm 3.48^{\mathrm{abc}}$ & $50.20 \pm 12.85^{\mathrm{bc}}$ & $33.73 \pm 3.89^{\mathrm{ab}}$ & $12.92 \pm 1.41^{\mathrm{b}}$ & $42.83 \pm 34.01^{b}$ \\
\hline $\mathrm{C2}$ & $12.76 \pm 0.93$ & $55.15 \pm 2.51^{\mathrm{abc}}$ & $69.47 \pm 6.04^{\mathrm{ab}}$ & $20.68 \pm 13.37^{\mathrm{abc}}$ & $4.28 \pm 7.30^{\mathrm{d}}$ & $38.47 \pm 25.93^{\mathrm{b}}$ \\
\hline C3 & $17.92 \pm 1.79$ & $61.13 \pm 4.29^{\mathrm{a}}$ & $46.67 \pm 1.55^{\mathrm{c}}$ & $35.94 \pm 0.40^{\mathrm{a}}$ & $13.47 \pm 2.04^{\mathrm{a}}$ & $69.89 \pm 28.24^{\mathrm{b}}$ \\
\hline $\mathrm{C4}$ & $16.24 \pm 0.28$ & $52.99 \pm 6.48^{\mathrm{abc}}$ & $82.16 \pm 1.76^{\mathrm{a}}$ & $31.19 \pm 0.36^{\mathrm{ab}}$ & $9.00 \pm 0.52^{\mathrm{cd}}$ & $50.70 \pm 50.27^{b}$ \\
\hline
\end{tabular}

$\mathrm{V}$ : vanilla ice cream, $\mathrm{K}$ : chocolate ice cream, C: strawberry ice cream

* a, b, c Means within a row with different lowercase letters show significant differences between ripening materials, $\mathrm{P}<0.05$ 
Using different stabilizers, Badem [30] determined the effect of these stabilizers on the ice cream quality and found that the hardness value of the ice cream prepared with $0.2 \%$ carrageenan was $157.316 \mathrm{~N}$, followed by the carrageenan ice cream $(140.286 \mathrm{~N})$ and carrageenan-free ice cream (93.299 $\mathrm{N})$.

\subsection{Rheological properties}

The consistency index and flow behavior index of the samples were calculated according to the power low model and apparent viscosity (Table 3). It was used to determine the flow characteristics of mixtures. All samples were found to exhibit pseudoplastic flow, where $\mathrm{n}<1$ (Figure 1).

The apparent viscosity decreased with an increase in the shear rate (Figure 2). The highest apparent viscosity value was found between 0.59 and $1.28 \mathrm{~Pa}$.s in the vanilla ice cream samples, $0.14-0.85 \mathrm{~Pa} \cdot \mathrm{s}$ in the strawberry ice cream samples and 2.17-7.73 $\mathrm{Pa} \cdot \mathrm{s}$ in the chocolate ice cream samples on the first day of storage at $10{ }^{\circ} \mathrm{C}$ at $50 \mathrm{~s}^{-1}$.

Table 3. The consistency coefficient and flow behavior index values of the ice cream mix samples at $10^{\circ} \mathrm{C}$

\begin{tabular}{cccc}
\hline & $\mathbf{K}$ & $\boldsymbol{n}$ & $\mathbf{R}^{\mathbf{2}}$ \\
\hline $\mathbf{V 1}$ & 32.0 & 0.62 & 99.28 \\
$\mathbf{V 2}$ & 33.8 & 0.65 & 99.57 \\
$\mathbf{V 3}$ & 34.6 & 0.67 & 99.46 \\
$\mathbf{V 4}$ & 31.8 & 0.61 & 99,34 \\
\hline $\mathbf{K 1}$ & 1748 & 0.30 & 98.55 \\
$\mathbf{K 2}$ & 1695 & 0.33 & 99.17 \\
$\mathbf{K 3}$ & 1847 & 0.32 & 98.76 \\
$\mathbf{K 4}$ & 1715 & 0.34 & 98.97 \\
\hline $\mathbf{C 1}$ & 518 & 0.23 & 99.79 \\
$\mathbf{C 2}$ & 532 & 0.24 & 99.68 \\
$\mathbf{C 3}$ & 545 & 0.28 & 99.47 \\
$\mathbf{C 4}$ & 498 & 0.22 & 99.86 \\
\hline
\end{tabular}

Errors in $\eta, K$ and $n$ were $\pm 1 \%, \pm 1 \%$, and $\pm 2 \%$, respectively

V: Vanilla ice cream C: Strawberry ice cream, K: chocolate ice cream

The visible viscosity values in the chocolate frost samples were determined to be higher than the other samples. Dervisoglu and Yazici [5] reported that they determined the apparent viscosity values to be 0.18-1.091 $\mathrm{Pa} \cdot \mathrm{s}$ at $20{ }^{\circ} \mathrm{C}$; Karaman and Kayaciger [6] measured the apparent viscosity to be $1.13 \mathrm{~Pa} \cdot \mathrm{s}$ at $10^{\circ} \mathrm{C}$.

The flow behavior index was found to be 0.61-0.67 in vanilla ice cream at $10{ }^{\circ} \mathrm{C}, 0.30-0.34$ in chocolate ice cream and $0.22-0.28$ in strawberry ice cream in the yoghurt ice cream samples (Table 3 ).

The flow behavior index was the highest in vanilla ice cream and the lowest in strawberry ice cream. Kaya and Tekin [3] determined the $\mathrm{n}$ value to be between 0.77 and 0.96 in sahlep ice cream with different ratios. Karaman and Kayaciger [6] reported that the flow behavior index in ice cream mixtures ranged from 0.269 to 0.356 at $20{ }^{\circ} \mathrm{C}$.

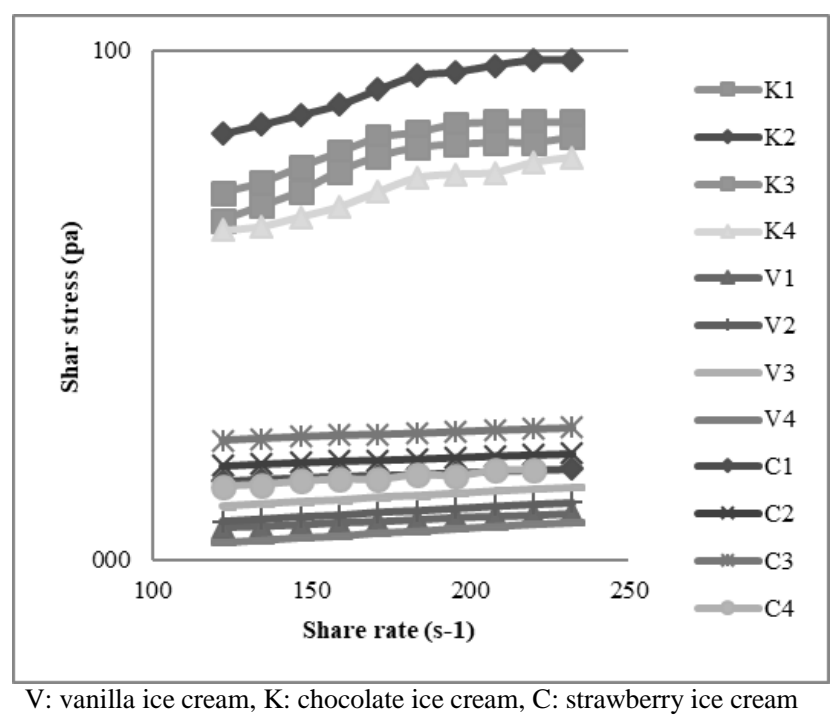

Figure 1. Apparent viscosity and share rate relationship of ice cream samples

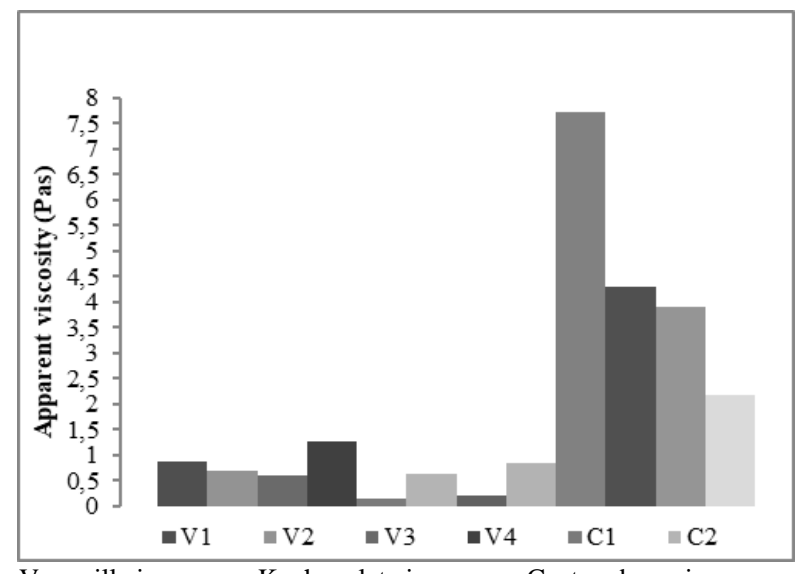

$\mathrm{V}$ : vanilla ice cream, $\mathrm{K}$ : chocolate ice cream, C: strawberry ice cream

Figure 2 Apparent viscosity and share rate relationship of ice cream samples

The consistency index was the lowest in the vanilla ice cream samples (31.8-34.6 Pa•s) followed by strawberry ice cream (518-545 Pa・s) and chocolate ice cream (1695-1847 $\mathrm{Pa} \cdot \mathrm{s})$. The difference between the $\mathrm{K}$ and $\mathrm{n}$ values was evaluated by variance analysis and the difference was found to be statistically significant $(p<0.05)$. The value of the consistency index in chocolate ice cream was significantly higher than the other samples. Kaya and Tekin [3] reported that the consistency index was determined to be between 66.65 and 540.62 in samples containing $0.78 \%$ sahlep. Karaman and Kayaciger [6] determined the consistency index was $11-19.90 \mathrm{~Pa} \bullet \mathrm{s}$ at $20{ }^{\circ} \mathrm{C}$ in ice creams containing different aroma compounds (herbal tea and black).

\subsection{Sensorial properties}

Some sensory properties (color, appearance, texture, odor and taste) of flavored ice cream are given in Table 4. While the statistical difference between the color appearance, odor and taste properties is not significant 
between the samples, it was seen that the difference between the texture properties was significant ( $\mathrm{p}<0.05$ ).

Principal component analysis was applied to demonstrate the state of the properties of the ice cream samples and shown in Figure 3. The variance of the first two axes is greater than 1, the eigenvalue value of the first principal component is 7.422 and explains $42.47 \%$ of the total variance. Axis 2 (PC2) describes $20.50 \%$ of the variance. The sum of the first two axes describes $62.97 \%$ of the variance.

The primary major component has the same sign and was sorted by the distance from zero corresponding to the frosted structure $(-0.35)$, smooth structure $(-0.34)$, acidic flavor $(-0.27)$, milk flavor (0.35), creamy flavor (0.35) orodispersibility (0.33), gummy structure (0.29) and sticky structure (0.25). The second major component is the insipid flavor (-0.32), glossy appearance (0.55), moire appearance (0.53) and granular appearance $(0.40)$.

According to these results, the major component scores for the vanilla ice cream samples were positive $(2.87,0.95$, 2.30 and 3.17), the chocolate ice cream samples were negative and positive $(0.15,-1.80,0.14$ and -2.22$)$ and the strawberry ice cream samples were positive and negative $(-1.37,5.93$ and 0.85$)$, while the second component scores were positive in the $\mathrm{V} 1, \mathrm{C} 1, \mathrm{C} 3, \mathrm{~V} 4$ and $\mathrm{K} 4$ samples (1.98, $3.43,0.18,1.62$ and 1.11) and have negative values in the other samples. According to these results, while the vanilla ice cream samples (V1, V4) were granular in appearance and gummy and fragile in structure (orodispersibility), the milk taste was creamy and without a sticky structure; the most prominent features in the $\mathrm{K} 1, \mathrm{~K} 3, \mathrm{~V} 2, \mathrm{C} 2, \mathrm{C} 4$ and V3 sampl The $\mathrm{C} 1$ and $\mathrm{K} 4$ samples were moire, glossy, acidic and sweet flavored, whereas K2 had an insipid flavor with a smooth structure.

In the cluster analysis used to determine the degree of closeness of the ice cream samples taken from the different types and different manufacturers, it was seen that the samples can be divided into 3 groups. When the related dendrograms were examined, the first group consists of the sample areas $\mathrm{C} 1, \mathrm{C} 2, \mathrm{C} 4, \mathrm{C} 3$ and $\mathrm{V} 4 \mathrm{in} \mathrm{I} 1, \mathrm{~V} 1, \mathrm{~K} 3, \mathrm{~K} 1$ and $\mathrm{V} 3$ in $\mathrm{I} 2$ and the other groups V2, K2 and $\mathrm{K} 4$ in $\mathrm{I} 3$.

Table 4. Sensory results of flavored ice cream

\begin{tabular}{ccccc}
\hline & $\begin{array}{c}\text { Color and } \\
\text { Appearance }\end{array}$ & Structure & $\begin{array}{c}\text { Odor and } \\
\text { Flavor }\end{array}$ & Total \\
\hline V1 & $4.40 \pm 0.51$ & $3.63 \pm 0.44^{\mathrm{ab}}$ & $3.65 \pm 0.71$ & 11.69 \\
V2 & $4.16 \pm 0.32$ & $3.66 \pm 0.35^{\mathrm{ab}}$ & $3.98 \pm 0.36$ & 11.82 \\
V3 & $3.38 \pm 0.57$ & $3.50 \pm 0.07^{\mathrm{ab}}$ & $3.61 \pm 0.32$ & 10.50 \\
V4 & $4.29 \pm 0.63$ & $4.21 \pm 0.32^{\mathrm{a}}$ & $3.70 \pm 0.63$ & 12.21 \\
\hline K1 & $3.95 \pm 0.50$ & $3.75 \pm 0.66^{\mathrm{ab}}$ & $3.67 \pm 0.09$ & 11.38 \\
K2 & $3.67 \pm 0.36$ & $3.66 \pm 0.45^{\mathrm{ab}}$ & $3.17 \pm 0.43$ & 10.52 \\
K3 & $3.27 \pm 0.14$ & $3.40 \pm 0.22^{\mathrm{ab}}$ & $3.53 \pm 0.34$ & 10.21 \\
K4 & $4.34 \pm 0.67$ & $4.38 \pm 0.64^{\mathrm{a}}$ & $4.11 \pm 0.48$ & 12.84 \\
\hline C1 & $3.84 \pm 0.35$ & $3.92 \pm 0.53^{\mathrm{ab}}$ & $4.16 \pm 0.40$ & 11.94 \\
C2 & $3.69 \pm 0.82$ & $4.11 \pm 0.48^{\mathrm{ab}}$ & $3.85 \pm 0.65$ & 11.66 \\
\hline C3 & $3.27 \pm 0.28$ & $2.90 \pm 0.29^{\mathrm{b}}$ & $2.94 \pm 0.27$ & 9.11 \\
& $3.61 \pm 0.65$ & $4.11 \pm 0.33^{\mathrm{ab}}$ & $3.60 \pm 0.62$ & 11.34 \\
\hline Va & & & & \\
\hline & & & & \\
\hline
\end{tabular}

V: Vanilla ice cream C: Strawberry ice cream, K: chocolate ice cream

* a, b: Means within a row with different lowercase letters show significant differences between ripening materials, $\mathrm{P}<0.05$

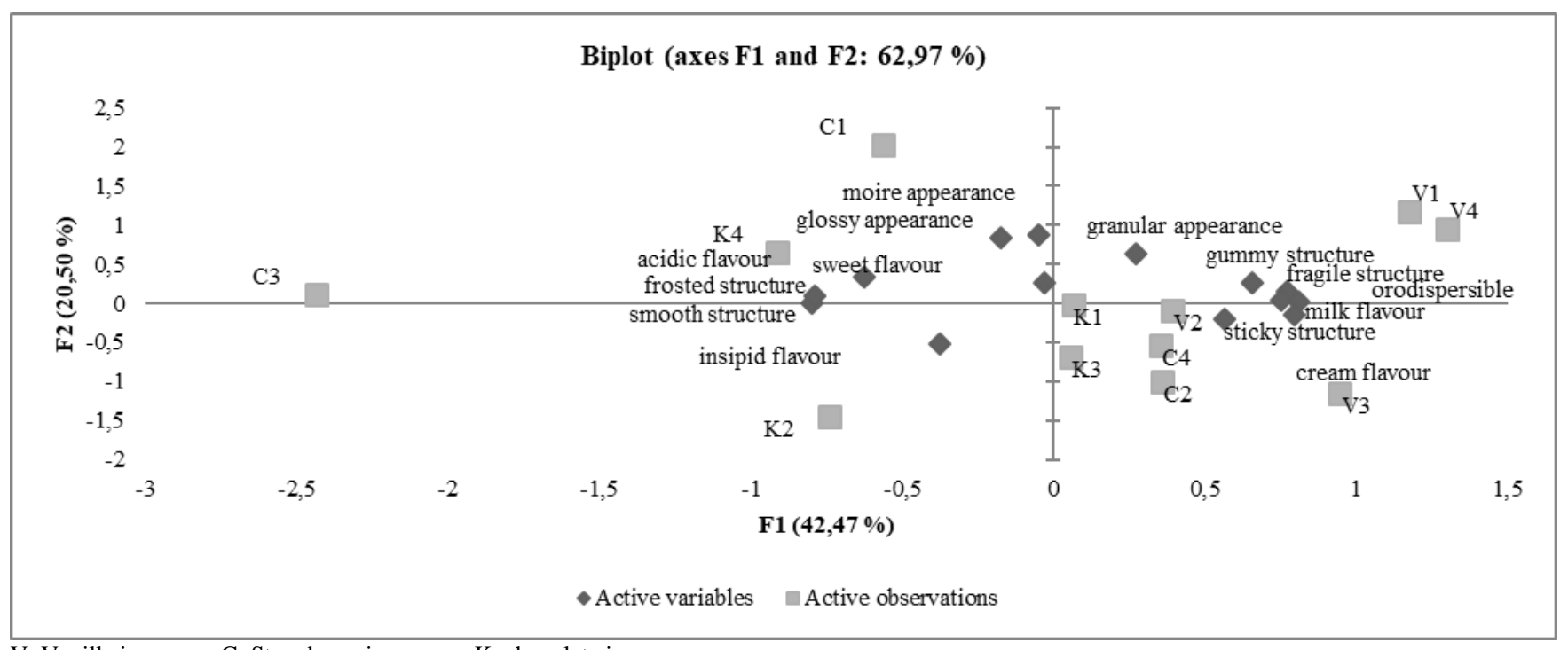

V: Vanilla ice cream C: Strawberry ice cream, K: chocolate ice cream

Figure 3. Principal components analysis of ice cream (sensory attributes data) as they affected by different flavor (vanilla, chocolate, and Strawberry) presence and storage time 
While the vanilla and chocolate samples were found to be partially related to each other due to their sensory and textural properties, the strawberry ice cream samples showed similarity among themselves.es were the cream and milk flavor, and sticky structure. The $\mathrm{C} 1$ and $\mathrm{K} 4$ samples were moire, glossy, acidic and sweet flavored, whereas $\mathrm{K} 2 \mathrm{had}$ an insipid flavor with a smooth structure.

In the cluster analysis used to determine the degree of closeness of the ice cream samples taken from the different types and different manufacturers, it was seen that the samples can be divided into 3 groups. When the related dendrograms were examined, the first group consists of the sample areas $\mathrm{C} 1, \mathrm{C} 2, \mathrm{C} 4, \mathrm{C} 3$ and $\mathrm{V} 4$ in $\mathrm{I} 1, \mathrm{~V} 1, \mathrm{~K} 3, \mathrm{~K} 1$ and $\mathrm{V} 3$ in $\mathrm{I} 2$ and the other groups V2, K2 and K4 in I3. While the vanilla and chocolate samples were found to be partially related to each other due to their sensory and textural properties, the strawberry ice cream samples showed similarity among themselves.

It has been determined that the vanilla, chocolate, and strawberry ice creams from four different producers have different flavor profiles from each other and are located separately in Figure 4. The samples with similar aroma profiles were determined at different locations in close proximity to each other as a result of the basic component analysis and at different locations for the ice cream samples with different aroma profiles. This shows us that different types of formulations can be used to produce ice cream even if the type properties are the same.

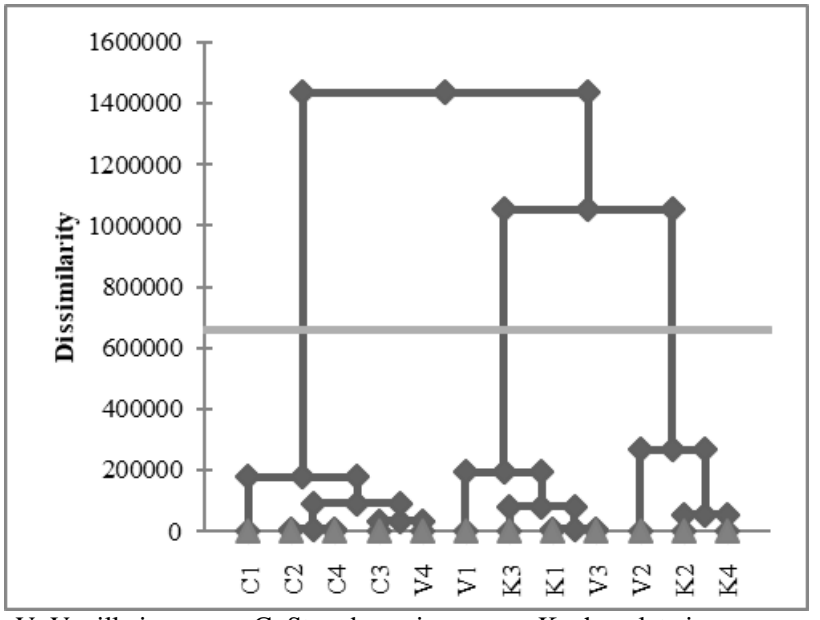

V: Vanilla ice cream C: Strawberry ice cream, K: chocolate ice cream

Figure 4. Inspection of the similarities among flavoured ice cream based on sensory properties data using cluster analysis

Soukoulis et al. [15] used key component and cluster analyses to determine the characteristics of ice cream and determine the degree of closeness in their studies. This explains the relationship between an ice cream's features and stabilizers.

\section{Conclusions}

Producers are producing ice cream with different characteristics and varieties according to consumer demand.
In this study, the chemical, rheological, textural and sensory properties of vanilla, chocolate and strawberry flavored ice cream in the market, which is thought to be widely produced, were determined and compared. Strawberry ice cream has a low fat and protein content and a relatively high acidity. It has been determined that there are very different color changes in the similar types of ice cream, and that the hardness properties show similarity between their types. In all the types of ice cream studied, a non-Newtonian pseudoplastic flow type was determined but different consistency coefficients were measured. Our sensory analyzes and statistical evaluations suggest that ice creams were produced with different properties, even if they have the same type characteristics.

Acknowledgments: This study was supported with 2841M-11 number by Suleyman Demirel University Scientific Research Department.

Conflict of interest: The authors declare that they do not have any conflict of interest.

\section{Similarity rate (iThenticate): $18 \%$}

\section{References}

[1] F. Coskun, Determination of fecal contamination in mere and strawberry ice cream sold in Tekirdag Province. Tekirdag Journal of Agriculture Faculty, 2 (2), 135-142, 2005.

[2] Ş. İbanoğlu and E. İbanoğlu, Rheological characterization of some traditional Turkish soups. Journal of Food Engineering 35, 251-256, 1998. https://doi.org/10.1016/S0260-8774(98)00016-8

[3] S. Kaya and A. R. Tekin, The effect of salep content on the rheological characteristics of a typical ice-cream mix. Journal of Food Engineering, 47, 59-62, 2001.

[4] O. C. Tekinşen ve A. Karacabey, Bazı stabilizer karışımlarının Kahramanmaraş tipi dondurmanın fiziksel ve organoleptik nitelikleri üzerine etkisi. TÜBİTAK Proje No:VHAG-594, Ankara, 48 s., 1984.

[5] M. Dervişoğlu and F. Yazici, The Effect of Fibre on the physical, chemical and sensory properties of ice cream. Food Sci. Tech. Int. 12 (2), 159-164, 2006. https://doi.org/10.1177/1082013206064005.

[6] S. Karaman and A. Kayaciger, Rheology of ice cream mix flavored with black tea or herbal teas and effect of flavoring on the sensory properties of ice cream. Food and Bioprocess Technology 5(8), 3159-3169, 2012. https://doi.org/10.1007/s11947-011-0713-5

[7] C. Cogne, J. Andrieu, P. Laurent, A. Besson and J. Nocquet, Experimental data and modelling of thermal properties of ice creams. Journal of Food Engineering, 58, 331-341, 2003. https://doi.org/10.1016/S02608774(02)00396-5

[8] Z. Li, R. H. Marshall and H. L. Fernando, Effect of milk fat content on flavor perception of vanilla ice cream. J. Dairy Sci. 80, 3133-3141, 1997.

[9] TS 4265- Dondurma - Süt Esasl1, Türk Standartları Enstitüsü. Ankara, 1992. 
[10] A.O.A.C (Offical Methods of Analysis), 17th Ed., Association of Official Analytical Chemist Virginia, USA, 2002.

[11] P. S. Christiansen, D. Edelsten, J. R. Kristiansen, and E. W. Nielsen, Some properties of ice cream containing Bifidobacterium bifidum and Lactobacillus acidophilus. Milchwisseschaft, 51, 502-504, 1996.

[12] A. Koyun, Endüstriyel dondurma üretiminde yağsız süt tozu yerine, peyniraltı suyu protein konsantresi kullanımının dondurmaya uygunluğunun araştırılması, Yüksek Lisans Tezi, Namık Kemal Üni. Fen Bilimleri Enstitüsü, Türkiye, 2009.

[13] R. T. Marshall, H. D. Goff and R. W. Hartel, Ice cream, Kluwer Academic/Plenum Publishers, New York, 2003.

[14] Z. Xuewu, L. Xin, G. Dexiang, Z. Wei, X. Tong and M. Yonghong, Rheological models for xanthan gum. Journal of Food Engineering 27, 203-209, 1996. https://doi.org/10.1016/0260-8774(94)00092-1

[15] C. Soukoulis, I. Chandrinos and C. Tzia, Study of the functionality of selected hydrocolloids and their blends with K-carrageenan on storage quality of vanilla ice cream. Food science and technology, 41, 1816-1827, 200, https://doi:10.1016/j.lwt.2007.12.009.

[16] F. W. Bodyfelt, J. Tobias, and G. M. Trout, The sensory evaluation of dairy product. New York: Van Nostrand Reinhold, 1988.

[17] J. X. Guinard, C. Zoumas-Morse, L. Mori, B. Uatoni, D. Panyam and A. Kilara, Sugar and fat effects on sensory properties of ice cream. Journal of Food Science, 62, 1087-1094, 1997. https://doi.org/10.1111/ j.1365-2621.1997.tb15044.x.

[18] M. Meilgaard, G. Vance, B. Civille and T. Carr, Sensory Evaluation Techniques. CRS press, US, 2007.

[19] S. Evrensel ve E. Güneş, Bursa'da tüketilen dondurmaların kimyasal ve mikrobiyolojik kalitesi. Gida, 23 (4), 261-265, 1998.

[20] T. Özcan, ve E. Kurdal, Bursa ili merkezinde satılan meyveli dondurmaların kimyasal ve mikrobiyolojik nitelikleri üzerine araştırma. Gıda, 22 (3), 217-225, 1997.

[21] F. Antepüzümü, Bal ve glukoz şurubu kullanımının Kahramanmaraş tipi dondurmaların kalite üzerine etkileri, Yüksek Lisans Tezi, Çukurova Üniversitesi Fen Bilimleri Enstitüsü, Türkiye, 2005.

[22] M. Güven, O. B. Karaca, A. Kaçar, A. A. Hayaloğlu ve K. Yaşar, Farklı stabilizörlerle üretilen Kahramanmaraş tipi dondurmaların fiziksel kimyasal ve duyusal özellikleri. Çukurova Üni. Ziraat Fak. Dergisi, 18 (1), 1-8, 2002.

[23] E. Atsan ve A. Çağlar, Dondurmanın bazı fiziksel ve duyusal özellikleri üzerine farklı emülgatörlerin etkisi, Atatürk Üniv. Ziraat Fak. Derg. 39 (1), 75-81, 2008.

[24] M. Güven, O. B. Karaca ve A. Kaçar, Yağ ikame maddelerinin yă oranı azaltılmıs Maraş usulü dondurmaların özellikleri üzerine etkileri. Çukurova Üni. Ziraat Fak. Dergisi, 23 (1), 7-14, 2008.

[25] M. R. Muse, and R. W. Hartel, Ice cream structural elements that affect melting rate and hardness. Journal of Dairy Science, 87 (1), 1-10, 2004.

[26] M. Dervişoğlu, F. Yazici, and O. Aydemir, The effect of soy protein concentrate addition on the physical, chemical, and sensory properties of stawberry flavored ice cream. European Food Research and Technology 221, 446-470, 2005. https://doi.org/10.1007/s00217005-1207-3.

[27] C. Aliyev, Kefir ve yaban mersininin dondurmanın fizikokimyasal, duyusal ve mikrobiyolojik özelliklerine etkisi, Yüksek Lisans Tezi, Ondokuz Mayıs Üni. Fen Bilimleri Enstitüsü, Türkiye, 2006.

[28] M. K. Walker, D. F. Farkas, V. Loveridge and L. Meunier-Goddik, Fruit yogurt processed with high pressure. International Journal of Food Science and Technology 40, 1-4, 2005. https://doi:10.1111/j.13652621.2005.01084.x.

[29] R. A. Wilbey, T. Cooke, and G. Dimos, Effects of solute concentration, overrun and storage on the hardness of ice cream. Procedings of the International Symposium Held in Athens, Greece, 18-19 September 1997.

[30] A. Badem, Keçiboynuzlu pekmezli dondurma üretiminde kullanılan karragenan, ksantan ve keçiboynuzu zamklarının dondurmaların kaliteleri üzerine etkisi, Yüksek Lisans Tezi, Akdeniz Üniversitesi, Fen Bilimleri Enstitüsü, Türkiye, 2006. 